\title{
Properties of TS-casein in aqueous alcohol solutions
}

\author{
Yasuo Igarashi and Zenichi SaIto \\ (Faculty of Agriculture, Hirosaki University) \\ (Received for Publication on April 10, 1971)
}

In the last paper ${ }^{4}$, TS-casein was separated from temperature sensitive fraction by gel filtration on Sephadex G-100, and such properties as amino acid composition, approximate molecular weight and turbidity were reported. For the convenience of further studies of this protein, the procedure of the separation was modified, and properties of TS-casein in alcohol solutions, especially in aqueous ethanol, were investigated in the present paper.

\section{Materials and Methods}

Preparation of TS-casein: Temperature sensitive fraction (TSF) was used as a starting material to separate TS-casein. The same procedure as described in the previous paper ${ }^{8 /}$ was carried to separate TSF from acid casein. TSF in $0.027 \mathrm{M}$ 2-amino-2-methyl-1-propanol$0.0089 \mathrm{M}$ citric acid buffer $(\mathrm{pH} 8.0$ ) was concentrated by means of ultrafiltration through a membranefilter (Sartorius). The concentrate was applied on a TEAE cellulose column of which temperature was held at $40^{\circ} \mathrm{C}$. The concentration procedure could be omitted by mixing TSF directly with wet TEAE cellulose, which had been equilibrated in the buffer solution, then the mixture was warmed to $40^{\circ} \mathrm{C}$, under continuous stirring, and poured into a glass column. Then, $100 \mathrm{ml}$ of the above mentioned buffer solution was passed through at $40^{\circ} \mathrm{C}$. After the elution, the column was held in a cold room $\left(2-4^{\circ} \mathrm{C}\right)$ overnight, and then, TS-casein was eluted by the buffer solution at $2-4^{\circ} \mathrm{C}$. Each ten milliliter amount of the effluent was collected and their absorbancies at $280 \mathrm{~m} \mu$ (at $10^{\circ} \mathrm{C}$ ) and $610 \mathrm{~m} \mu$ (at $30^{\circ} \mathrm{C}$ ) were measured by Hitachi EPU-2 A spectrophotometer.

Starch gel electrophoresis: Method of Sснм1Dт ${ }^{7)}$ was used for the preparation of starch gel. Horizontal electrophoresis was carried out in a cold room $\left(2-4^{\circ} \mathrm{C}\right)$ with $1 \mathrm{~mA} / 1 \times 0.5 \mathrm{~cm}^{2}$ applied.

Electrofocusing: Electrophoresis was carried out at $2^{\circ} \mathrm{C}$ in an electrofocusing column (LKB-Producter) according to the procedure of VESTERBERG and SvENSSON ${ }^{8}$ ) with a modification which added urea at $5 \mathrm{~m}$ as final concentration in both of a dense and a less dense solution. A carrier ampholyte, $\mathrm{pH}$ 3-10 (LKB-Producter) was used for the formation of a $\mathrm{pH}$ gradient. An effluent monitor (Hitachi 034) and a pH meter (Hitachi $\mathrm{F} 5$ equipped with micro flow-type electrode Horiba 6901-25 T) were also used for the measurement of absorbancy and $\mathrm{pH}$, respectively.

Measurement of turbidity: The turbidity was examined as described previously ${ }^{4}$.

Stability in aqueous ethanol: TS-casein and whole casein were dialyzed against $0.05 \mathrm{M}$ phosphate buffer (pH 7.0) for 24 hours. The precipitate formed during dialysis was removed by filtration (Toyo filter paper No. 2). Two milliliter of the filtrate (protein concentration $0.96 \mathrm{mg} / \mathrm{ml}$ ) was mixed with $2 \mathrm{ml}$ of aqueous ethanol $(10-99.5 \%)$ and left for 24 hours. The 
mixtures were centrifuged $(1,000 \mathrm{G}$, for $10 \mathrm{~min}$.), and nitrogen in $3 \mathrm{~m} l$ of the supernatant was determined by the micro Kjeldahl method. All procedures were carried out in a cold room $\left(2-4^{\circ} \mathrm{C}\right)$ except for the determination of nitrogen. TS-casein was also dialyzed against deionized water for 24 hours. Two milliliter of the TS-casein solution was mixed with $1 \mathrm{~m} l$ of a buffer solution $\left(0.084 \mathrm{M}-0.064 \mathrm{M}\right.$ citric acid-0.032 $\mathrm{M}-0.19 \mathrm{M} \mathrm{Na} \mathrm{HPO}_{4}$, for $\mathrm{pH} 2.9-7.6$, $0.028 \mathrm{M}-0.043 \mathrm{M}$ sodium borate- $0.045 \mathrm{M}-0.015 \mathrm{M} \mathrm{HCl}$, for $\mathrm{pH} 7.9-9.1$ ), and $1 \mathrm{~m} l$ of absolute ethanol was added. Fifty percent ethanol solutions were also made by mixing $1.5 \mathrm{~m} l$ of TScasein, $0.5 \mathrm{~m} l$ of every buffer solution and $2 \mathrm{~m} l$ of absolute ethanol. The mixtures were analyzed as described above. After centrifugation the $\mathrm{pH}$ of the supernatant was measured at $2-4^{\circ} \mathrm{C}$ by a $\mathrm{pH}$ meter (Hitachi $\mathrm{M} 4$ ) which was equipped with a needle type electrode (Horiba 6201).

\section{Results}

TSF obtained from acid casein by TEAE cellulose column chromatography was applied to another temperature-controlled TEAE cellulose column. An elution diagram of TSF is seen in Fig. 1. Column temperature was controlled as shown in the figure. The eluates at peaks of the diagram were subjected to starch gel electrophoresis (Fig. 2). Elution at $40^{\circ} \mathrm{C}$ permitted the column to adsorb TS-casein and removed impurities (Peak a) from it. It had been shown by another experiment that the column temperature of $30^{\circ} \mathrm{C}$ was not enough for all of the TS-casein to be adsorbed. Temperature change from $40^{\circ} \mathrm{C}$ to $20^{\circ} \mathrm{C}$ permitted a considerable part of TS-casein to elute as Peak b (Fig. 1). All of the TS-casein which remained in the column was eluted from it by holding the column temperature at $2-4{ }^{\circ} \mathrm{C}$. The

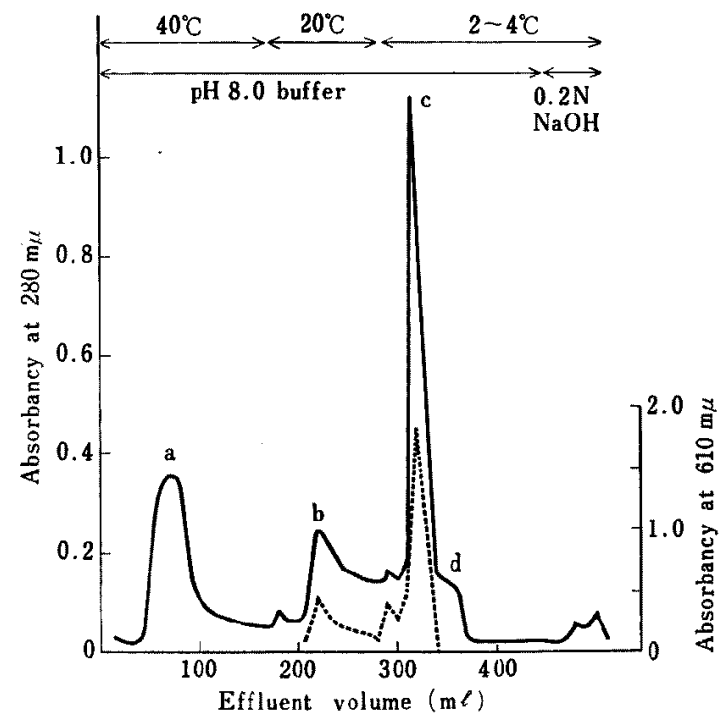

Fig. 1. A chromatogram of TSF on TEAE cellulose

Column temperature was varied as indicated in the figure. A solid line and a dotted line indicate absorbancy at $280 \mathrm{~m} \mu$ (at $10^{\circ} \mathrm{C}$ ) and $610 \mathrm{~m} / \mu$ (at $30^{\circ} \mathrm{C}$ ) respectively. Ten milliliter fractions were collected at a flow rate of $50 \mathrm{~m} / / \mathrm{hr}$. Buffer: $0.027 \mathrm{M} 2$-amino-2-methyl-1-propanol-0.0089 M citric acim, $\mathrm{pH} 8.0$. 


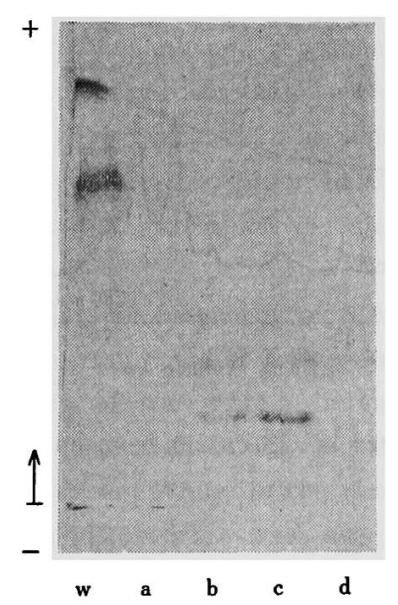

Fig. 2. Starch gel electrophoresis of fractions obtained from Fig. 1 (a-d) and whole casein (w) Tris-citrate buffer, $\mathrm{pH} 8.6$ with $7 \mathrm{M}$ urea and $0.022 \mathrm{M}$ 2-mercaptoethanol (ScHMIDT ${ }^{7)}$ )

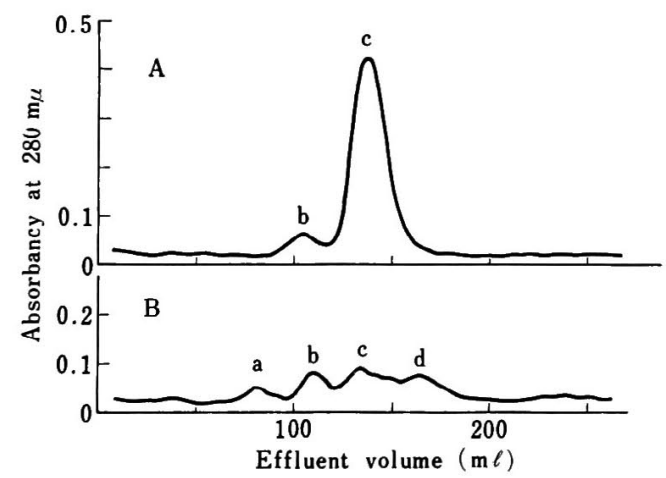

Fig. 3. Gel filtration through Sephadex G-100 of TS-casein (A) and impurities (B)

Buffer: 0.027 M 2-amino-2-methyl-1-propanol-0.0089 M citric acid, pH 8.0 column size: $2.8 \times 4.8 \mathrm{~cm}$. Five milliliter fractions were collected at a flow rate of $24 \mathrm{ml} / \mathrm{hr}$ in a cold room $\left(2-4^{\circ} \mathrm{C}\right)$

elution buffer was not changed throughout the entire course. TS-casein and impurities separated by this procedure were applied on a Sephadex G-100 column (Fig. 3). Peak a and $d$ were absent in Fig. 3 (above), although a trace of Peak b was observed.

Fig. 4 shows an elution pattern of TS-casein from an electrofocusing column, with $5 \mathrm{M}$ urea, at $2^{\circ} \mathrm{C}$. TS-casein consisted of two components in respect to isoelectric point, $\mathrm{pH} 6.7$ and $\mathrm{pH}$ 7.3. An experiment with no urea caused precipitation at the end of the electrophoresis which disturbed the formation of the peaks in the pattern. 


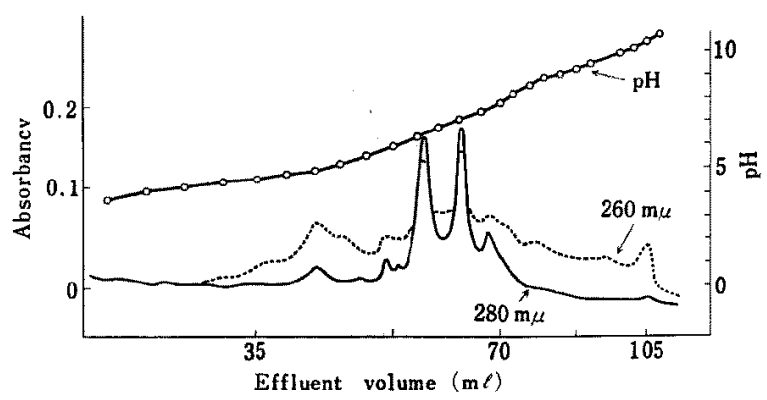

Fig. 4. Elution pattern of TS-casein from an electrofocusing column

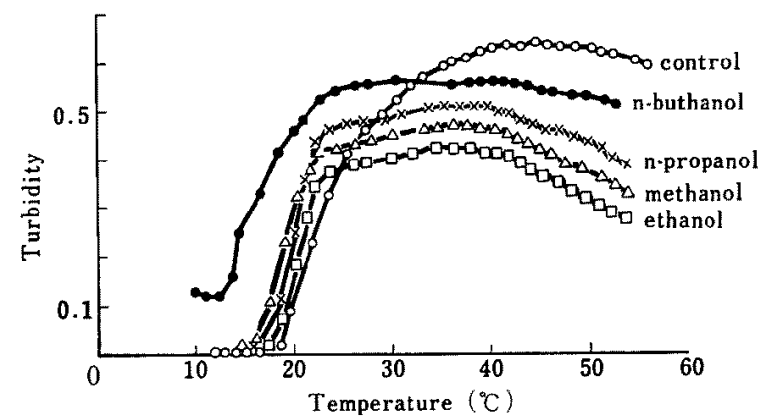

Fig. 5. Effect of various alcohols on the turbidity of TS-casein Alcohol concentration: $5 \%(v / v)$ Buffer: $0.05 \mathrm{M}$ phosphate, $\mathrm{pH} 7.0$

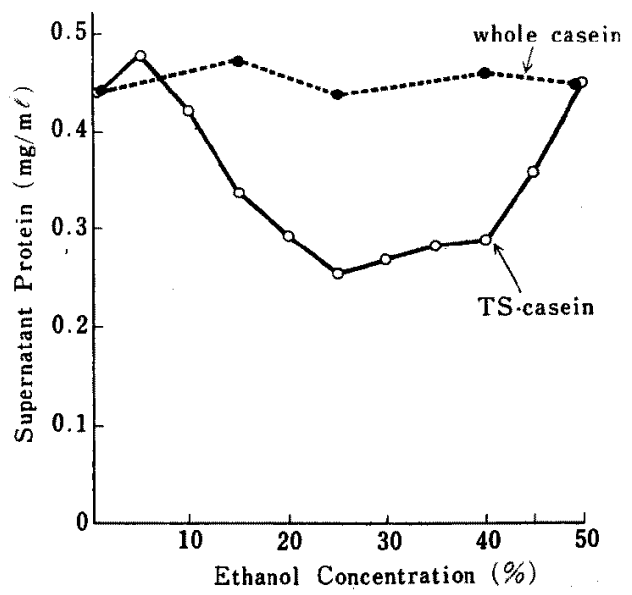

Fig. 6. Effect of ethanol concentration on the stability of TS-casein and whole casein

Buffer: $0.05 \mathrm{M}$ phosphate, pH 7.0 
Mixtures of TS-casein (protein concentration $0.35 \mathrm{mg} / \mathrm{ml}$ ) in $0.05 \mathrm{M}$ phosphate buffer solution ( $\mathrm{pH} 7.0$ ) and alcohols (methanol, ethanol, n-propanol, n-buthanol) were made at a final alcohol concentration of $5 \%$ in volume, and their turbidities at the temperature between 10 and $55^{\circ} \mathrm{C}$ were measured (Fig. 5). The temperature at which the turbidity increased rapidly was lowered by addition of alcohols. On the other hand, the maximum turbidities of the mixtures were lower than that of control to which deionized water was added instead of alcohol.

Aliquot portions of TS-casein (protein concentration $0.96 \mathrm{mg} / \mathrm{ml}$ ) and whole casein $(0.95$ $\mathrm{mg} / \mathrm{ml}$ ) in $0.05 \mathrm{M}$ phosphate buffer solution $(\mathrm{pH} 7.0)$ were mixed with an equal volume of $10-99.5 \%$ ethanol to observe stability of the protein in various concentrations of aqueous ethanol solutions. The results are presented in Fig. 6. Whole casein was not precipitated up to final ethanol concentration of $50 \%$. While, in the case of TS-casein in the existence of ethanol at $15-45 \%$ concentrations, visible precipitates were formed after 24 hours at $2-4^{\circ} \mathrm{C}$. In Fig. 6, minimum stability was observed at $25 \%$ aqueous ethanol. The bottom part of the curve, however, distributes in considerably wide range from 20 to $40 \%$ ethanol concentrations. TS-casein was completely solubilized when ethanol concentration reached to $50 \%$. The stability of TS-casein in $25 \%$ and $50 \%$ ethanol solutions was further observed, in a pH from 3.6 to 10.5 (Fig. 7). Protein in supernatant decreased, when the ethanol concentration was $25 \%$, in a wide $\mathrm{pH}$ range, i.e. from $\mathrm{pH} 4.1$ to 8.8 , amounting $35-55 \%$ of total protein. At the ethanol concentration of $50 \%$, minimum recovery was observed at $\mathrm{pH} 5.9-6.9$ and the amount of protein in supernatant was higher than the case of $25 \%$ ethanol in a wide $\mathrm{pH}$ range as seen in the figure.

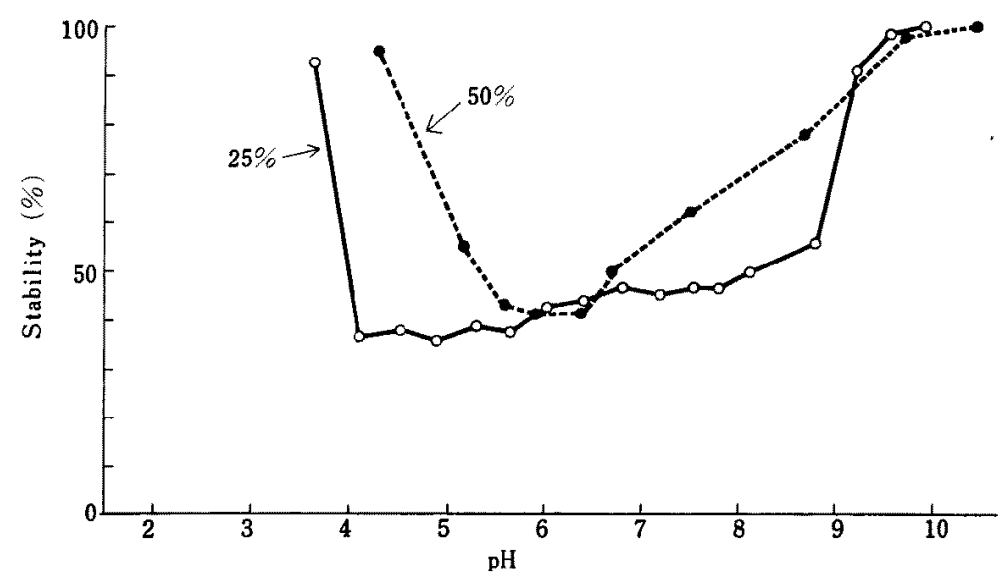

Fig. 7. Effect of $\mathrm{pH}$ on the stability of TS-casein in $25 \%$ and $50 \%$ aqueous ethanol

\section{Discussion}

TS-casein was separated from temperature sensitive fraction by adsorption on TEAE cellulose at $40^{\circ} \mathrm{C}$. When a TS-casein solution is warmed, self-association is caused to form stable micelles ${ }^{3,4}$. With the co-existence of TEAE cellulose at this condition, TS-casein interacted more closely with the adsorbent than the association of TS-casein itself. The 


\section{IGARASHI - SAITO}

technique was convenient and almost all of the TS-casein was recovered by only lowering the temperature of the adsorbent from $40^{\circ} \mathrm{C}$ to $2-4^{\circ} \mathrm{C}$. The technique also provided somewhat an unusual method in regard to the use of ion-exchange cellulose, when applied to temperaturesensitive protein such as TS-casein. The adsorption, however, was not clearly understood whether on account of the increase in ionic attraction between protein and adsorbent at higher temperature or the increase in hydrophobic force which was studied thermodynamically by NEMETHY and SHERAGA ${ }^{5}$.

Thus separated TS-casein was the same for the most part as that of previously described ${ }^{41}$ in respect to starch gel electrophoresis and Sephadex gel filtration. Isoelectric focussing experiment revealed that the protein consisted mainly of two components which differed in their isoelectric points in $5 \mathrm{~m}$ urea. This difference seems to be due to the genetic polymorphism of TS-casein that was recently observed by GRoves ${ }^{2}$, rather than due to the existence of another protein such as $\gamma$ - or $R$-casein because the two peaks were almost the same in amount and such amount of two components were not observed by starch gel electrophoresis.

Addition of alcohols to $5 \%$ concentration in TS-casein solution affected a turbidity curve in each case. Effect of alcohols, in this case, should be considered from both sides i.e. alteration of water structure surrounding protein and action on protein itself.

In a low alcohol concentration and at below room-temperature, hydrogen-bonded water structure so called clusters ${ }^{6)}$ may be altered, and this may cause the changes of the stability of side chain of the protein molecule in contact with the solvent.

Aqueous ethanol is often employed for the detection of stability of milk on some manufacturing treatments. ARIMA et al. ${ }^{13}$ reported that the minimum concentration of calcium ion in order to obtain a clear detection of stability of casein in ethanol solutions was about $5 \mathrm{~mm}$. It was confirmed by our experiment that whole casein is stable in aqueous ethanol in the absence of calcium. In the case of TS-casein, however, it was found out that calcium was not necessary for precipitation in ethanol solutions. This seems to be related with the previous observation that the turbidity was not influenced by the addition of calcium ${ }^{4}$.

Minimum stability was obtained when the ethanol concentration was $25 \%$. In this solvent, TS-casein precipitated in a wide $\mathrm{pH}$ range from 4,1-8.8. The $\mathrm{pH}$ independence of the low solubility in a $25 \%$ ethanol solution suggests participation of non-ionic binding, namely, hydrophobic binding, between protein molecules. Probably, conformational changes of the protein in this solution may make these binding easier.

The increase in ethanol concentration would be favoured for the solvation of the nonpolar side chains. A high ratio of the hydrophobic groups of amino acids seems to make the protein stabilize in a high concentration of ethanol.

It would be noticeable that TS-casein precipitated at similar concentration of ethanol to the case of alcohol-test of milk.

\section{Summary}

TS-casein was separated from temperature sensitive fraction by adsorption on TEAE cellulose at $40^{\circ} \mathrm{C}$ and recovered by cooling the adsorbent to $2-4^{\circ} \mathrm{C}$ in the same buffer solution. TS-casein separated by this procedure agreed with that previously described in respect to gel filtration on Sephadex G-100, and consisted of a major and two minor components by starch gel electrophoresis in the presence of $7 \mathrm{M}$ urea and $0.022 \mathrm{M} 2$-mercaptoethanol. An electro- 
TS-casein in alcohol solutions

focusing experiment showed two major components (isoelectric point: 6.7 and 7.3 ) in the existence of $5 \mathrm{M}$ urea.

Each addition of $5 \%$ (at the final concentration) methanol, ethanol, n-propanol, and $\mathbf{n}$-buthanol to TS-casein solution affected its turbidity curve. In a $25 \%$ ethanol solution, TS-casein precipitated in a wide $\mathrm{pH}$ range (4.1-8.8). The minimum stability in $50 \%$ ethanol was observed at $\mathrm{pH} \mathrm{5.9-6.9}$ and the stability was higher than in $25 \%$ ethanol except in this $\mathrm{pH}$ range.

\section{Acknowledgements}

The authors are grateful to Dr. S. Arima, Professor of the Faculty of Agriculture, Hokkaido University, for his precious advice and discussions. This study was supported in part by a Grant-in-Aid for Scientific Research from the Ministry of Education.

\section{References}

1) Arima, S., S. Hori., R. Niki and Y. Hashimoto (1964) Jap. J. Zootech. Sci., 35: 130-136.

2) Groves, M.L. (1969) J. Dairy Sci., 52: 1155-1165.

3) Igarashi, Y. and Z. SAIto (1968) Jap. J. Zootech. Sci., 39: 78-83.

4) IgaRashi, Y. and Z. SaIto (1970) Jap. J. Zootech. Sci., 41: 262-269.

5) Némethy, G. and H.A. Scheraga (1962) J. Phys. Chem., 66: 1773-1789.

6) Scheraga, H.A. (1963) The proteins Vol. 1. 2 ed. 517-518. Academic Press. N.Y.

7) Schmidt, D.G. (1964) Biochim. Biophys. Acta., 90: 411-414.

8) Vesterberg, O. and H. Svensson (1966) Acta Chem. Scand., 20: 820-834. 


\title{
TS-カゼインのアルコール溶液中における性質について
}

\author{
五十䖝康雄・斎 藤 善 一
}

(弘前大学農学部)

前報に拉々て, Temperature sensitive fraction (TSF) よりセファデックス G-100さ用いたダルる過に 上りTS-カげイン定分離して，そのアミノ酸組成，分 于量，濁度に抢上ぼす潪類の影篦などについて報告した 方，本蛋白質の性質崖さらに研究子万ため，分離方法在 改善し，フルコール溶液中に岕ける本蛋白質の性質につ いて，主に安定性の面から調ハるため本実驗を行なっ た.

酸っだインより TSF の調製まては同棁でるるが，本 報では TSF $40^{\circ} \mathrm{C}$ に保たれた TEAE七ルロースカ ラムに加え，同温度で 2-アミノー2-メチルー1-プロパノ ールータエン酸緩衝液（pH 8.0）で溶出させた後（区分 1), 力 分 3）に下げて同綑畺液で溶出した。濁度およびでんぷ えダル電気泳動によりしらベた結果，区分1には TS-

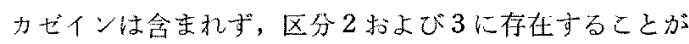

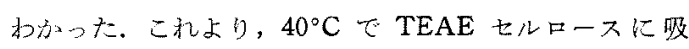

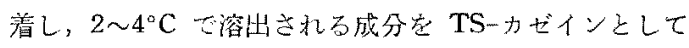
实験に倛した。本成分はセフォデッタス $\mathrm{G}-100$ 苑用い

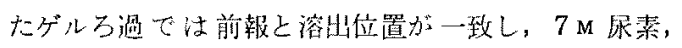
$0.022 \mathrm{M} 2$ 2-メルカプトエ夕ノール念含むでえか゚えゲル霄
気泳動では主要成分の外に少量の 2 成分が認められた。 エレタトロフォ一カシングによれ发，5 $\mathrm{M}$ 㽷素中て等電 点が $\mathrm{pH} 6.7$ と 7.3 の 2 成分が認められた. TS-力ゼ イン溶液にメタノール，エタノール，n-プロパノール， nープタノ一ル最䅂濃度で5\%になるように加えると， いずれも対照より低い温度で濁度が上曻したが，最高濁 度は低かった。 TSーカゼイン少よび全力ゼイン定種々の エタノ一ル䟴度と種々の $\mathrm{pH}$ の溶液中において一夜放置 $\left(2 \sim 4^{\circ} \mathrm{C}\right)$ した復，遠沈 $(1,000 \mathrm{G}, 10$ 分)して上澄の 蛋白質含量家ミクロケルダール注により測定した結果, $\mathrm{pH} 7.0$ の紱衝液に透析した時は，全力ゼインは土タ， 一ル濃度 $50 \%$ まで沈殿を生じなかったが，TSーカゼイ ンは 15 45\% で沈殿を生じ，25\%で最も沈殿が多かっ たが，50\%では再び可溶性となった。エタノール濃度 $25 \%$ の場合, pH 4.1〜8.8 で TS-カゼインの 45-65\% が沈殿し，pH 3.6 以下と 9.5 以上で可溶性であった. また，エタノール祳度 $50 \%$ の時では， $\mathrm{pH} 6$ 付近で最 も沈殿が多かったが $(60 \%)$ これ以外の $\mathrm{pH}$ 域では, $25 \%$ の時より沈殿晏が少なかった。以上の性犋は前報 で報告した柾水性アミノ酸が多いことと何らかの関連性 があるものと思秃た。 